\title{
Ghrelin Agonist JMV 1843 Increases Food Intake, Body Weight and Expression of Orexigenic Neuropeptides in Mice
}

\author{
M. HOLUBOVÁ ${ }^{1}$, A. ŠPOLCOVÁ ${ }^{1}$, Z. DEMIANOVÁ ${ }^{1}$, D. SÝKORA ${ }^{2}$, J. A. FEHRENTZ ${ }^{3}$, \\ J. MARTINEZ ${ }^{3}$, A. ŠTOFKOVÁ ${ }^{4}$, J. JURČOVIČOVÁ ${ }^{4}, J_{\text {. DRÁPALOVÁ }}^{5}, \mathrm{Z}_{\text {. LACINOVÁ }}^{5}$, \\ M. HALUZÍK ${ }^{5}$, B. ŽELEZNÁ ${ }^{1}$, L. MALETÍNSKÁ ${ }^{1}$ \\ ${ }^{1}$ Institute of Organic Chemistry and Biochemistry, Academy of Sciences of the Czech Republic, \\ Prague, Czech Republic, ${ }^{2}$ Institute of Chemical Technology, Department of Analytical Chemistry, \\ Prague, Czech Republic, ${ }^{3}$ IBMM UMR 5247, CNRS-Universités Montpellier 1- Montpellier 2, \\ Faculté de Pharmacie, Montpellier, France, ${ }^{4}$ Department of Normal, Pathological and Clinical \\ Physiology, Third Faculty of Medicine, Charles University, Prague, Czech Republic, ${ }^{5}$ Third \\ Department of Medicine, First Faculty of Medicine, Charles University, Prague, Czech Republic
}

Received November 23, 2012

Accepted February 12, 2013

On-line April 16, 2013

\begin{abstract}
Summary
Ghrelin and agonists of its receptor GHS-R1a are potential substances for the treatment of cachexia. In the present study, we investigated the acute and long-term effects of the GHS-R1a agonist JMV 1843 (H-Aib-DTrp-D-gTrp-CHO) on food intake, body weight and metabolic parameters in lean C57BL/6 male mice. Additionally, we examined stability of JMV 1843 in mouse blood serum. A single subcutaneous injection of JMV 1843 (0.01-10 $\mathrm{mg} / \mathrm{kg})$ increased food intake in fed mice in a dosedependent manner, up to 5 -times relative to the saline-treated group $\left(E D_{50}=1.94 \mathrm{mg} / \mathrm{kg}\right.$ at $\left.250 \mathrm{~min}\right)$. JMV 1843 was stable in mouse serum in vitro for $24 \mathrm{~h}$, but was mostly eliminated from mouse blood after $2 \mathrm{~h}$ in vivo. Ten days of treatment with JMV 1843 (subcutaneous administration, 10 or $20 \mathrm{mg} / \mathrm{kg} /$ day) significantly increased food intake, body weight and mRNA expression of the orexigenic neuropeptide $Y$ and agouti-related peptide in the medial basal hypothalamus and decreased the expression of uncoupling protein 1 in brown adipose tissue. Our data suggest that JMV 1843 could have possible future uses in the treatment of cachexia.
\end{abstract}

\section{Key words}

GHS-R agonists • JMV 1843 • Male C57BL/6 mice • Food intake • NPY/AgRP

\section{Corresponding author}

L. Maletínská, Institute of Organic Chemistry and Biochemistry,
Flemingovo nám. 2, 16610 Prague 6, Czech Republic. Fax: +420 220183571. E-mail: maletin@uochb.cas.cz

\section{Introduction}

Ghrelin is an endogenous ligand of the growth hormone secretagogue receptor (GHS-R). Structurally, ghrelin is a linear 28-amino-acid peptide with an octanoyl acid bound to $\mathrm{Ser}^{3}$ that is necessary for its biological activity but is highly prone to fast hydrolysis (Kojima et al. 1999). Due to the limited half-life of the octanoylated ghrelin, more stable analogs are being developed for potential clinical use.

Ghrelin is the only known orexigenic gut hormone that acts directly in the brain by enhancing both the expression and secretion of the orexigenic neuropeptide Y (NPY) and agouti-related peptide (AgRP) (Cowley et al. 2003, Chen et al. 2004). Although ghrelin was originally discovered as an endogenous growth hormone $(\mathrm{GH})$ secretagogue with the potential to be used in the treatment of GH deficiency (Kojima et al. 1999), attention is currently focused more on ghrelin analogs with orexigenic effects that have potential applications in the treatment of cachexia.

In long-term studies, ghrelin and its peptide agonists such as BIM-28125 and BIM-28131, designed by IPSEN, increased body fat but not lean body mass in 
lean rats, and this effect was independent of GH-releasing action (Tschöp et al. 2000, Strassburg et al. 2008). Under conditions of chronic wasting states, such as cachexia in chronic kidney disease, adjuvant arthritis or heart failure, ghrelin and BIM-28125 and BIM-28131 preferably prevented muscle wasting by attenuating muscle proteolysis (Deboer et al. 2008) or by the expression of ubiquitin ligases preventing muscle atrophy (Palus et al. 2011) but not by anabolic action.

Two orally active ghrelin agonists, TZP-102 of Tranzyme Pharma for the treatment of gastroparesis and anamorelin of Helsinn for the treatment of cachexia/anorexia in patients with non-small cell lung cancer are in clinical testing phase 2 and 3, respectively.

The ghrelin peptide agonist [Aib-DTrp-DgTrpCHO] named JMV 1843, formerly known as EP-1572 (Broglio et al. 2002, Guerlavais et al. 2003) was originally designed as a GH secretagogue. JMV 1843 was demonstrated to have high binding affinity for both human pituitary cell membranes and LLC PK-1 cells transfected transiently with human GHS-R1 (Guerlavais et al. 2003) where this compound also activated MAPK/ERK1/2 (Mousseaux et al. 2006). In young dogs, JMV 1843 was shown to stimulate growth hormone secretion (Guerlavais et al. 2003). In healthy men, orally or subcutaneously (SC) administered JMV 1843 rapidly and dose-dependently enhanced its concentration in the blood plasma and subsequently stimulated growth hormone secretion (Piccoli et al. 2007). JMV 1843 was tested as AEZS-130 in Phase 3 clinical trial to assess the use of this compound as a diagnostic tool in adults with GH deficiency and has also been tested in Phase 2 study for the treatment of cachexia by Aeterna Zentaris.

The goal of this study was to investigate the acute and long-term effects of the SC-administered GHS-R1a agonist JMV 1843 on food intake, body weight and metabolic parameters in lean C57BL/6 mice. Additionally, we examined stability of the compound in mouse blood serum both in vitro and in vivo. Our results suggest that because of its prolonged stability compared with ghrelin and its ability to positively affect food intake, likely through the activation of hypothalamic NPY/AgRP neurons, JMV 1843 could have a potential to treat cachexia and malnutrition.

\section{Methods}

Synthesis of the GHS-Rla agonist JMV 1843 JMV 1843 [H-Aib-DTrp-D-gTrp-CHO] was synthesized at IBMM UMR5247, Faculté de Pharmacie, Montpellier, as described by Guerlavais et al. (2003).

\section{Experimental animals}

All experiments followed the ethical guidelines for animal experiments and the Czech Republic law No. 246/1992 and were approved by the Committee for Experiments with Laboratory Animals of the Academy of Sciences of the Czech Republic.

Inbred C57BL/6 male mice (AnLab, Prague, Czech Republic) were housed at a temperature of $23{ }^{\circ} \mathrm{C}$ under a daily cycle of 12-hour periods of light and dark (light period starting at 6:00 a.m.). Mice had free access to water and a standard chow diet that contained $25 \%$, $9 \%$ and $66 \%$ of calories from protein, fat and carbohydrate, respectively (St-1, Mlýn Kocanda, Jesenice, Czech Republic).

Acute effect of the GHS-R agonist JMV 1843 on food intake

Fifteen-week-old mice were randomly divided into groups of 6 animals and were kept in separate cages for one week. Before the experiment, mice had free access to food and water. Thereafter, the food pellets were removed at 8:00 a.m. and the mice were injected SC with $0.2 \mathrm{ml}$ of saline or JMV1843 (dissolved in saline) at a dose ranging from 0.01 to $10 \mathrm{mg} / \mathrm{kg}$ of body weight (b.w.) ( $\mathrm{n}=6$ mice per group, b.w. 23-26 g). Fifteen minutes after the injection, mice were given preweighed food pellets. Food intake was monitored for $5 \mathrm{~h}$; the pellets were weighed at $30 \mathrm{~min}$ intervals and then returned to the cages and cumulative food intake was registered. Animals had free access to water during the experiment.

\section{Measurement of pharmacokinetics in the blood serum in vitro and in vivo}

For in vitro pharmacokinetics, the sera of adult male C57BL/6 mice were spiked with JMV 1843 to a final concentration of $10-6 \mathrm{M}$ and incubated at $37^{\circ} \mathrm{C}$. Samples were collected at $30 \mathrm{~min}, 1,2,4,8,24,48,72$, 96 and $144 \mathrm{~h}$ after the start of the incubation and were immediately frozen and stored at $-20^{\circ} \mathrm{C}$.

Simultaneously, fed 15-week-old male C57BL/6 mice were SC injected with $0.2 \mathrm{ml}$ of JMV 1843 (dissolved in saline) at a dose of 5 or $10 \mathrm{mg} / \mathrm{kg}$ of b.w. and sacrificed by decapitation at $10 \mathrm{~min}, 30 \mathrm{~min}, 1,2,4$ or $8 \mathrm{~h}$ after injection $(\mathrm{n}=3)$. Blood was collected and serum was isolated and stored at $-20^{\circ} \mathrm{C}$. 
In both experiments, JMV 1843 was extracted from serum using an acetonitrile precipitation of proteins as described previously (Hatziieremia et al. 2007). Samples were then subjected to an LC-MS system consisting of an Alliance HPLC (Waters, USA) and a Q-TOF-Micro hybrid mass spectrometer (Waters, USA). Chromatographic separation was carried out with a Discovery HS C18 column (Supelco, USA), with a particle size of $5 \mu \mathrm{m}$ and a column size of $50 \times 2.1 \mathrm{~mm}$ ID. Mobile phase A consisted of $0.1 \% \mathrm{HCOOH}$ in water, and mobile phase $\mathrm{B}$ contained $0.1 \% \mathrm{HCOOH}$ in acetonitrile. For the separation of analytes, a gradient from $5 \%$ to $100 \%$ B over 5.5 min was used at a flow rate of $200 \mu 1 / \mathrm{min}$.

\section{Effect of 10-day administration of the GHS-R agonist} JMV 1843 on food intake and metabolic parameters in mice

At the age of 16 weeks, mice were randomly divided into three groups of 10 animals and placed into separate cages with free access to food and water. The following week, mice were subjected to a 10-day food intake experiment. The mice were injected $\mathrm{SC}$ with saline or JMV 1843 at a dose of 10 or $20 \mathrm{mg} / \mathrm{kg}$ of b.w./day (twice a day at 8:00 a.m. and 6:00 p.m., single doses of 5 or $10 \mathrm{mg} / \mathrm{kg}$ of b.w., respectively) for 10 days. Consumption of the St-1 diet and the weight of the mice were monitored simultaneously.

At the end of the experiment, fed mice were sacrificed by decapitation at 8:00 a.m. Trunk blood was collected and plasma was prepared and stored at $-20{ }^{\circ} \mathrm{C}$. The white adipose tissue (WAT, abdominal plus gonadal adipose tissue), the subcutaneous adipose tissue (SCAT), the brown adipose tissue (BAT), the musculus gastrocnemius and the liver of all mice were dissected, weighed, flash-frozen in liquid nitrogen and stored at $-70{ }^{\circ} \mathrm{C}$. The rate of adiposity was expressed as fat-tobody weight ratio (ratio of the total adipose tissue weight to the total body weight). Brains were dissected, placed into isopentane at -15 to $-20^{\circ} \mathrm{C}$ for one minute, frozen on dry ice and kept at $-70^{\circ} \mathrm{C}$ until sectioning. Coronal sections $(200 \mu \mathrm{m})$ were cut (starting $-1.25 \mathrm{~mm}$ from the bregma) using a cryostat, mounted on glass slides, and immersed in absolute ethanol for $50 \mathrm{~s}$. Immediately thereafter the medial basal hypothalamus (including the median eminence, arcuate nuclei, ventromedial nuclei, and dorsomedial nuclei) was dissected with a razor blade from a series of sections under a microscope. The tissue was homogenized in RNA extraction lysis buffer, and kept at $-70{ }^{\circ} \mathrm{C}$ until RNA extraction.

\section{Determination of hormonal and biochemical parameters}

The plasma insulin and adiponectin concentrations were measured by RIA assays (Linco Research, St. Charles, MI, USA), and leptin and IGF-1 concentrations were determined by ELISA assays (Linco Research, St. Charles, MI, USA and BioVendor, Heidelberg, Germany, respectively). The blood glucose levels were measured using a Glucocard glucometer (Arkray, Kyoto, Japan). All measurements were carried out according to the protocols recommended by the manufacturers.

\section{Determination of $m R N A$ expression}

Samples of adipose tissue (BAT, WAT) and muscle were homogenized, total RNA was extracted and RNA concentration was determined as previously described (Maletínská et al. 2011). Determination of the mRNA expression of genes of interest (uncoupling protein 1 (UCP1) in brown adipose tissue; uncoupling protein 2 (UCP2), acetyl-CoA carboxylase 1 (ACACA), fatty acid synthase (FASN), lipoprotein lipase (LPL) and stearoyl-CoA desaturase 1 (SCD-1) in abdominal plus gonadal adipose tissue; myostatin, myogenin, myosin heavy chain 4 (MHC4) and insulin-like growth factor 1(IGF-1) in muscle) was performed using an ABI PRISM 7500 instrument (Applied Biosystems, Foster City, CA, USA). The expression of $\beta 2$ microglobulin (B2M) was used to compensate for variations in input RNA amounts and the efficiency of reverse transcription, and the modified formula $2-\Delta \mathrm{Ct}$ was used to calculate the relative gene expression.

Total RNA from the medial basal hypothalamus was isolated using the RNAqueous Micro Kit (Ambion, Austin, TX). The concentration of RNA for the target genes NPY and AgRP was determined as detailed previously (Stofkova et al. 2010). Input RNA amounts were calculated with a multiple comparative method for the mRNAs of interest and GAPDH. Statistical analysis was performed using GenEx Ver. 5 software (MultiD Analyses AB, Goteborg, Sweden).

\section{Statistical analysis}

The data are presented as the means \pm SEM for the number of animals indicated in the figures and tables. The data were analyzed by a two-way analysis of variance (ANOVA) followed by a Bonferroni post-hoc test (food intake and body weight evaluation), one-way 


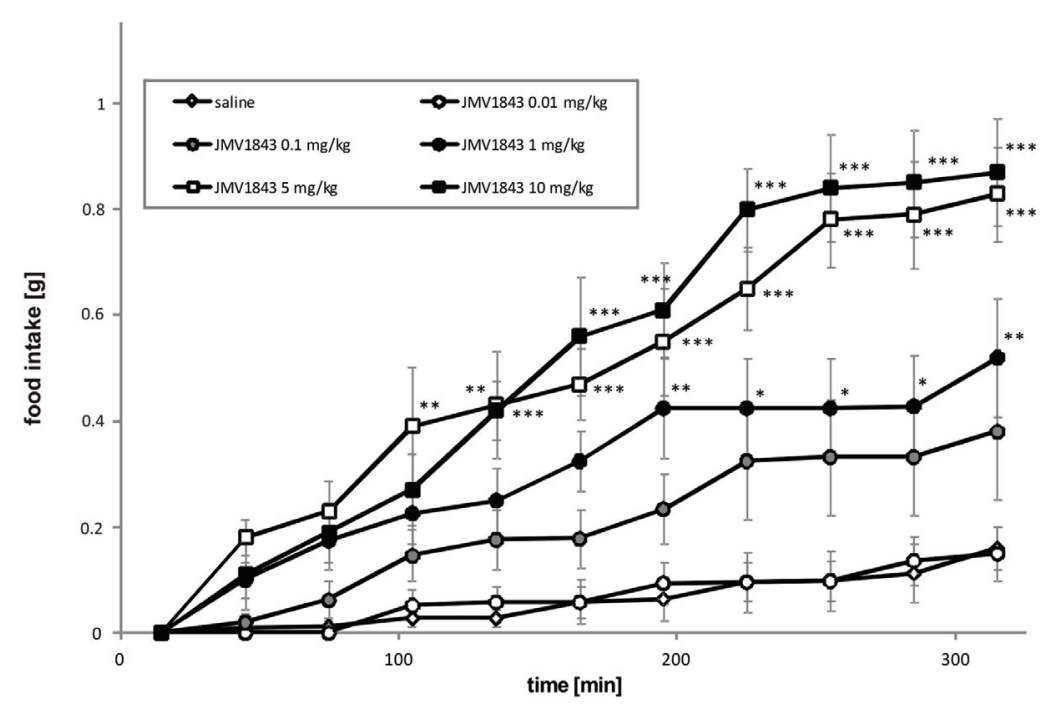

Fig. 1. Acute effect of JMV 1843 on food intake in C57BL/6 mice (SC administration, doses of $0.01,0.1,1,5$ and $10 \mathrm{mg} / \mathrm{kg}$ ). Food intake was monitored for $5 \mathrm{~h}$ after injection and is expressed in grams of food consumed. The data were analyzed by two-way ANOVA followed by a Bonferroni post-hoc test. The significance levels were $* \mathrm{P}<0.05, * * \mathrm{P}<0.01$, and $* * * \mathrm{P}<0.001$ vs. the saline-treated group $(n=6)$.
ANOVA followed by a Dunnett post-hoc test (metabolic parameters) or t-test (mRNA expressions), as indicated in the figures and table legends, using GraphPad Software (San Diego, CA, USA). $\mathrm{P}<0.05$ was considered statistically significant. In the acute food intake test, the ED50 value was calculated using GraphPad software as the dose of the compound required to elicit half-maximal consumption at $250 \mathrm{~min}$ after the injection of the compound (time of maximal effect).

\section{Results}

\section{Acute effects of JMV 1843 in lean mice}

The acute orexigenic effect of the SC administered ghrelin agonist JMV 1843 was determined in fed 15-week-old C57BL/6 mice using doses from 0.01 to $10 \mathrm{mg} / \mathrm{kg}$ of b.w. JMV 1843 increased food intake in fed mice in a dose-dependent manner, with an $\mathrm{ED}_{50}$ value of $1.94 \mathrm{mg} / \mathrm{kg}$ at $250 \mathrm{~min}$. Doses of 5 and $10 \mathrm{mg} / \mathrm{kg}$ caused greater than 5-fold increases in food intake compared with the administration of saline alone (Fig. 1).

\section{Pharmacokinetics of JMV 1843 in vitro and in vivo}

JMV 1843 showed good stability in vitro in mouse serum for $24 \mathrm{~h}$ when incubated at $37^{\circ} \mathrm{C}$, maintaining $50 \%$ of its initial concentration after $60 \mathrm{~h}$ (Fig. 2A). However, it was almost completely eliminated from mouse blood after $2 \mathrm{~h}$ following SC administration in mice, with elimination half-lives of 21 and $23 \mathrm{~min}$ at the doses of $5 \mathrm{mg} / \mathrm{kg}$ and $10 \mathrm{mg} / \mathrm{kg}$, respectively (Fig. 2B).
Effects of 10-day administration of JMV 1843 in lean mice

Our short-term food intake experiment showed that the use of $10 \mathrm{mg} / \mathrm{kg}$ of JMV 1843 resulted in the most significant increase in food intake. However, due to the relatively fast elimination of the compound from mouse blood, daily doses of 10 and $20 \mathrm{mg} / \mathrm{kg}$ of b.w., injected SC at doses of 5 and $10 \mathrm{mg} / \mathrm{kg}$, two times daily, respectively, were chosen for the 10-day administration experiment.

Ten days of treatment with JMV 1843 at both doses significantly increased average daily food intake (Fig. 3A) and body weight (Fig. 3B) compared with the saline control treatment. Treatment with JMV 1843 at a dose of $20 \mathrm{mg} / \mathrm{kg}$ of b.w./day significantly increased glucose level. However, at the $10 \mathrm{mg} / \mathrm{kg}$ of b.w./day dose, no effect on blood glucose was found. Circulating leptin levels were increased proportionally with the increased adiposity by both doses of JMV 1843 but changes in both parameters did not reach significancy. Despite these effects on food intake, body weight and adiposity, no significant changes in metabolic parameters, such as insulin, adiponectin and IGF-1 plasma levels, were detected (Table 1).

\section{Expression of NPY and AgRP $m R N A$ s in the medial basal} hypothalamus

Treatment with JMV 1843 at a dose of $20 \mathrm{mg} / \mathrm{kg}$ of b.w./day significantly increased the expression of mRNAs for the orexigenic peptides NPY and AgRP in medial basal hypothalamus comprising the median eminence, arcuate, paraventricular and dorsomedial nuclei (Fig. 4A,B). 

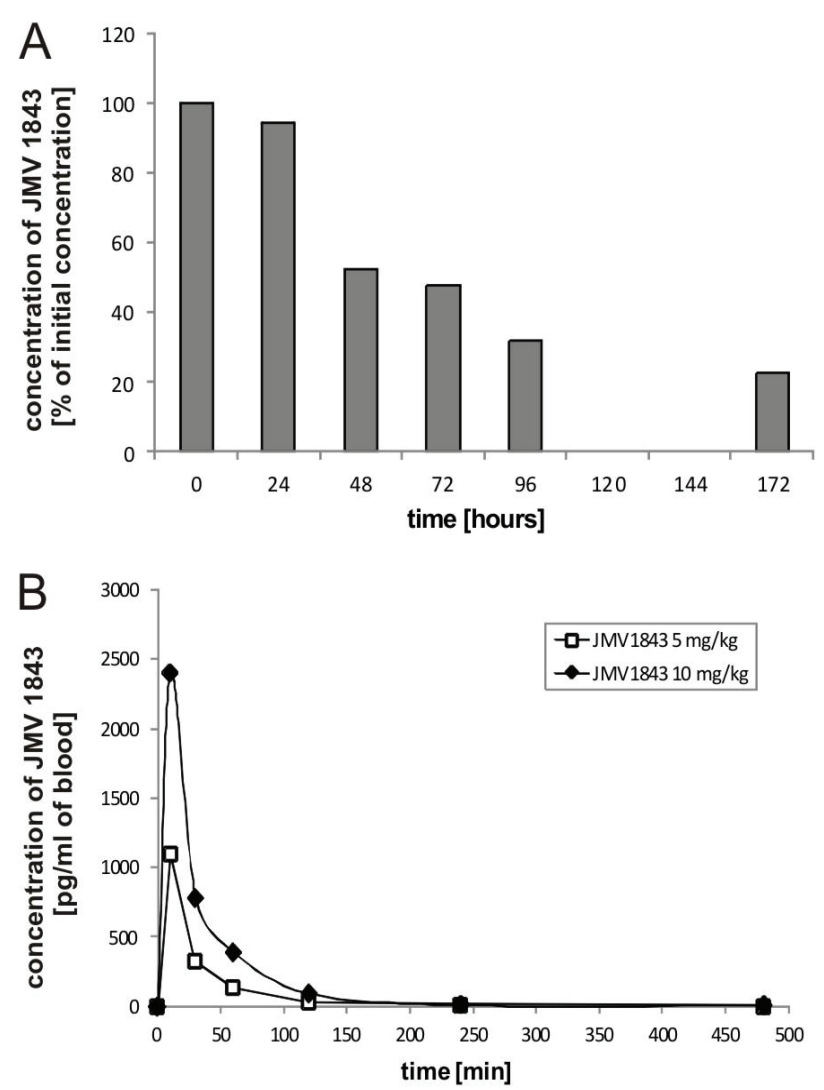

Fig. 2. Degradation profile of JMV 1843 (A) in mouse blood serum in vitro and (B) after administration to $\mathrm{C} 57 \mathrm{BL} / 6$ mice in vivo. (A) Mouse serum spiked with JMV $1843\left(10^{-6} \mathrm{M}\right)$ was incubated at $37^{\circ} \mathrm{C}$ for the indicated time periods. Samples prepared by acetonitrile precipitation were subjected to LC-MS analysis. The data are expressed as a percentage of the concentration at time zero. (B) Mice ( $n=3$ per group) were SC injected with JMV 1843 at the doses of 5 and $10 \mathrm{mg} / \mathrm{kg}$ and were sacrificed after the time periods indicated in the figure. Samples prepared by acetonitrile precipitation were subjected to LC-MS analysis. The data are expressed as the concentration of JMV1843.

\section{Discussion}

Ghrelin and other agonists of the growth hormone secretagogue receptor (GHSR-1a) are currently being investigated as potent therapeutic agents for the treatment of cachexia, a complex wasting syndrome accompanying a wide array of chronic diseases. Effects of ghrelin, such as increase in appetite, food intake and body adiposity, suggest its potential to counteract the symptoms of cachexia. Therefore ghrelin can help to preserve energy reserves and improve clinical outcomes in cachectic patients. Due to the limited stability of ghrelin and its short half-life in circulation, ghrelin analogs with greater stability are being developed for the treatment of cachexia.

In this study, we investigated the acute and longterm effects of the pseudopeptide GHS-R1a agonist
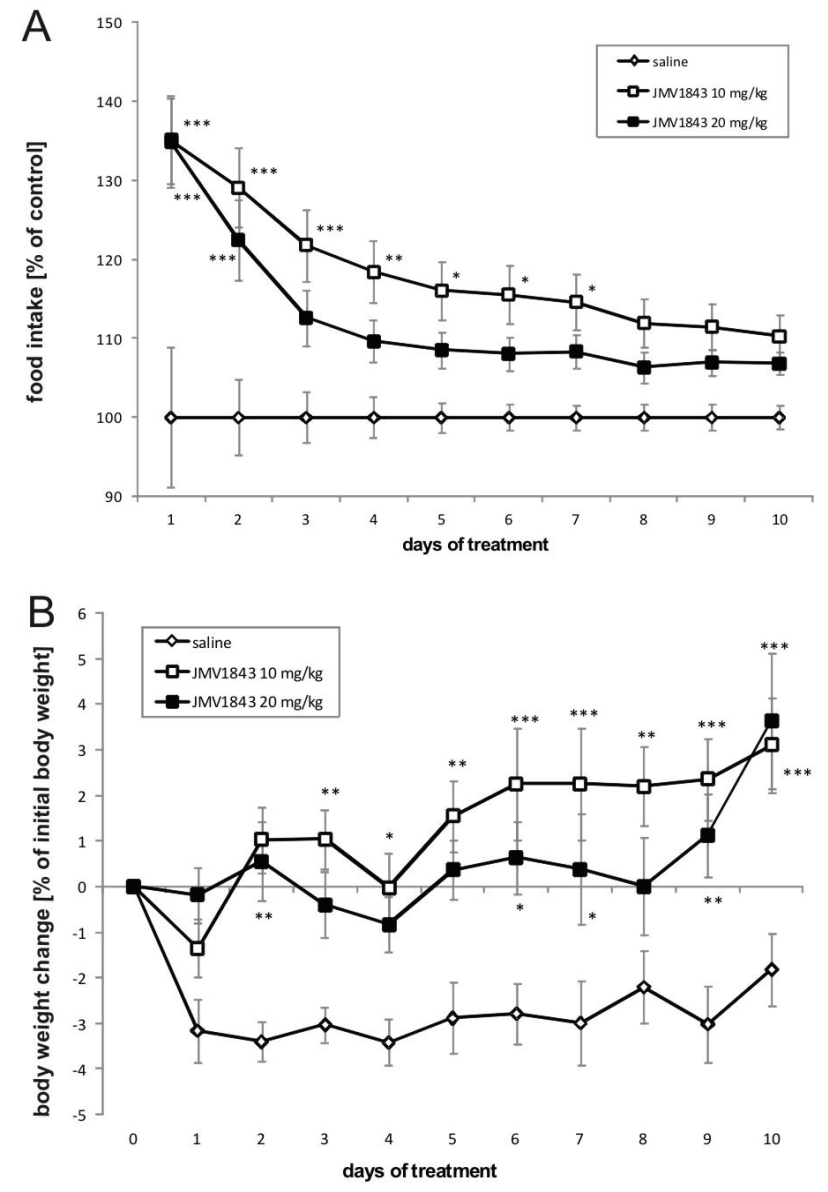

Fig. 3. Long-term effect of JMV 1843 on food intake and body weight in C57BL/ 6 mice (SC administration, 10 and $20 \mathrm{mg} / \mathrm{kg}$ of b.w./day, administered as 5 and $10 \mathrm{mg} / \mathrm{kg}$ twice per day for 10 days, respectively). Food intake and body weight were monitored daily. (A) Cumulative food intake expressed as a percentage of the food intake of the control group, (B) body weight change expressed as a percentage of the initial body weight. The data were analyzed by two-way ANOVA followed by a Bonferroni post-hoc test. The significance levels were $* \mathrm{P}<0.05$, ${ }^{* *} \mathrm{P}<0.01$, and $* * * \mathrm{P}<0.001$ vs. the saline-treated group $(\mathrm{n}=10)$.

JMV 1843 subcutaneously administered to lean C57BL/7 male mice. The data presented here clearly indicate that JMV 1843 positively affects food intake and body weight gain, suggesting its potential to beneficially affect disorders accompanied by chronically decreased food intake.

Similarly to the previously described $90 \mathrm{~min}$ food intake experiment (Pirnik et al. 2011), our dose response acute experiment showed that a single SC injection of JMV 1843 constantly stimulated 5-h food intake in ad libitum-fed lean mice during the light phase. JMV 1843 increased food consumption in a dose dependent manner, reaching statistical significance at a dose of $1 \mathrm{mg} / \mathrm{kg}$ of b.w. Doses of 5 and $10 \mathrm{mg} / \mathrm{kg}$ of b.w. caused greater than 5 -fold increases in food intake during the 5-h period, compared to the saline-treated group. 


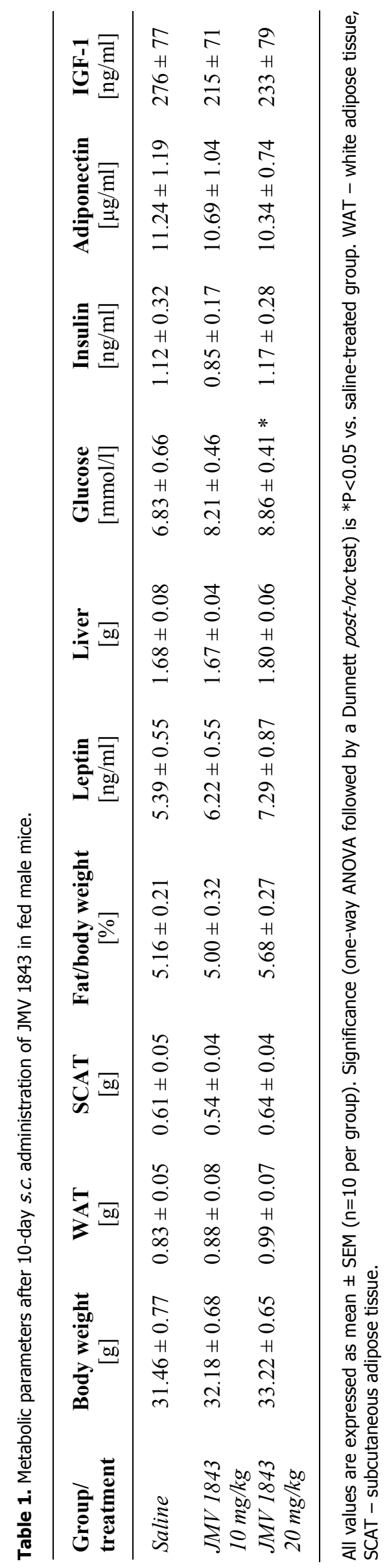



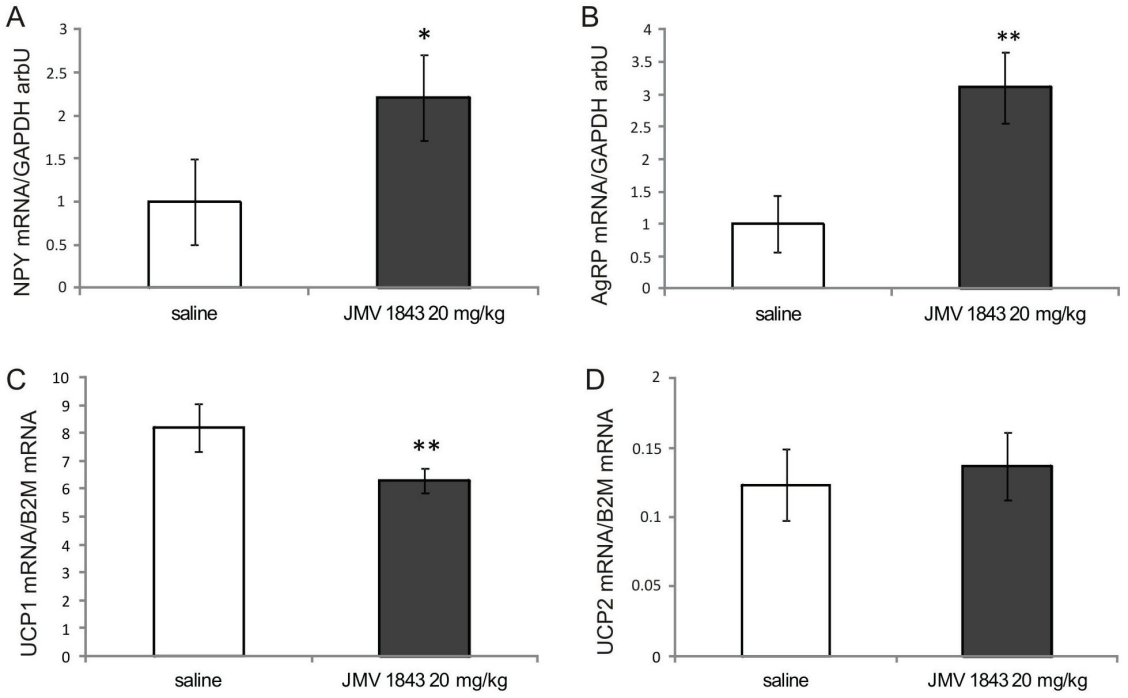

Fig. 4. Expression of mRNA in mouse tissues after 10-day administration of JMV1843 at a dose of $20 \mathrm{mg} / \mathrm{kg}$ of b.w./day: (A) NPY mRNA levels, (B) AgRP mRNA levels in the medial basal hypothalamus. The data were normalized to GAPDH and analyzed by the unpaired t-test. The significance levels were $* \mathrm{P}<0.05, * * \mathrm{P}<0.01$, and $* * * \mathrm{P}<0.001$ vs. the saline-treated group $(\mathrm{n}=10)$. (C) UCP1 mRNA levels in brown adipose tissue, (D) UCP2 mRNA levels in white adipose tissue. The data were normalized to $\beta_{2}$ microglobulin and analyzed by the unpaired $\mathrm{t}$-test. The significance levels were $\quad * \mathrm{P}<0.05, \quad * * \mathrm{P}<0.01, \quad$ and $* * * \mathrm{P}<0.001 \mathrm{vs}$, the saline-treated group $(n=10)$.
This increase was even greater than the one observed in our previous experiments with ghrelin at the same dose (Maletínská et al. 2012). The stronger potency of JMV 1843 could be due to its prolonged stability and more long-lasting effect relative to ghrelin. Ghrelin has been reported to have a short biological half-life of approximately 9-13 min, mostly due to the rapid desacylation of the peptide (Akamizu and Kangawa 2006). In contrast, the synthetic pseudopeptide JMV 1843 showed increased stability, with a half-life of 80-93 min after different doses of intradermal application in men (Piccoli et al. 2007). In our in vitro experiment examining the degradation of JMV 1843 in mouse serum, we showed that JMV 1843 remained almost completely stable for approximately $24 \mathrm{~h}$ and was present at $50 \%$ of its initial concentration after 2.5 days. However, ghrelin was degraded rapidly under the same conditions with a half-life of $12 \mathrm{~min}$, as shown in our previous study (Maletínská et al. 2012). The pharmacokinetics of JMV 1843 determined in vivo in mice after SC administration showed that the drug promptly entered blood stream, with a peak concentration $10 \mathrm{~min}$ after administration. Although JMV 1843 was found to be stable in vitro, it was almost completely eliminated from mouse blood after $2 \mathrm{~h}$ following the SC administration, having a biological half-life of 21-23 $\mathrm{min}$ and reaching a zero concentration after $4 \mathrm{~h}$. These observations suggest that JMV 1843 is either rapidly metabolized or accumulated in tissues.

JMV 1843 administered subcutaneously for ten days significantly increased the food intake and body weight of lean mice at both doses. Surprisingly, the effect of the lower dose was slightly more pronounced than the effect of the higher dose. This finding is most likely due to the lower solubility at the higher dose, reaching the maximal possible effect of the compound at the lower dose or saturation of influx mechanisms at the lower dose. Importantly, the weight gain at both doses was maintained until the last measurement, although the effect on food intake stayed significant for seven days and then dropped slightly. This finding seems to be consistent with the suggestion that mechanisms other than hyperphagia may mediate ghrelin-induced increase in body weight (Kim et al. 2004). It was previously demonstrated that chronic ghrelin treatment in lean mice decreased the expression of UCP1 in brown adipose tissue (Tsubone et al. 2005). UCP1, which is expressed predominantly in BAT mitochondria, is responsible for the high thermogenic capacity of BAT and regulates energy expenditure; it allows proton re-entry into the mitochondrial matrix without passing through ATP-synthase, which enables energy dissipation via the production of heat (Clapham 2011). In this study, we showed that a ten-day treatment with JMV 1843 significantly decreased the expression of UCP1 mRNA in BAT similarly to the above mentioned down-regulation of UCP1 mRNA after the treatment with ghrelin. This suggests a possible reduction of energy expenditure, which may also contribute to the described increase in body weight. Furthermore, treatment with JMV 1843 tended to increase the UCP2 mRNA level in WAT. This observation corresponds to the effect of ghrelin described by (Tsubone et al. 2005); however, the functional significance of this effect remains unknown.

To further dissect the mechanisms underlying the orexigenic effect of the chronic administration of JMV 1843, we examined the changes in the mRNA levels of NPY and AgRP in the medial basal hypothalamus. NPY 
and AgRP are potent orexigenic peptides co-expressed in subsets of neurons in the arcuate nucleus. It was shown that both central and peripheral chronic administration of ghrelin increase hypothalamic NPY and AgRP mRNA levels, indicating that NPY/AgRP containing neurons are the primary hypothalamic targets of ghrelin and obligatory mediators of its orexigenic effect (Kamegai et al. 2001, Chen et al. 2004). We found that the treatment with JMV 1843 significantly elevated NPY and AgRP mRNA expression, suggesting that the mechanism of action of JMV 1843 regarding food intake is similar to that described for ghrelin. In addition to orexigenic effects, both NPY and AgRP also decrease thermogenesis via the reduction of UCP1 production in BAT (Billington et al. 1994, Small et al. 2001). Therefore, it is plausible to hypothesize that the effects JMV 1843 on UCP1 mRNA expression in BAT could be mediated by the stimulation of hypothalamic NPY/AgRP neurons.

Ten days treatment with JMV 1843 moderately but non-significantly increased the white adipose tissue content and circulating leptin level. These results are in agreement with previous observations suggesting that ghrelin-induced weight gain of the whole body might be primarily induced by an increase in adiposity, while the weight of muscle mass and other organs remains unaffected (Tsubone et al. 2005). This conclusion is further supported by our finding that JMV 1843 had no effect on myogenesis markers and significantly decreased myogenin mRNA levels, indicating that the treatment did not affect muscle mass. However, results of mRNA expression analysis of fat metabolism genes did not confirm significant increase in adipogenesis. Nevertheless, neither adipose tissue nor muscle mass was decreased and orexigenic mechanisms were activated, which seems to be most important for potential use of the compound for the treatment of cachexia.

The above mentioned effects were in animals treated with $20 \mathrm{mg} / \mathrm{kg}$ of b.w./day dose of JMV 1843 accompanied by significantly increased blood glucose levels, which were not observed at the dose of $10 \mathrm{mg} / \mathrm{kg}$ of b.w./day. On the other hand, neither of the doses of JMV 1843 affected the serum concentrations of insulin, adiponectin and IGF-1, suggesting no deleterious effects on insulin sensitivity. These results are consistent with those of previous studies that examined the effects of the chronic administration of ghrelin (Kamegai et al. 2001, Nakazato et al. 2001, Kim et al. 2004).

\section{Conclusion}

In conclusion, we have shown that JMV 1843 has prolonged stability compared with ghrelin and increases food intake and body weight in lean mice through the activation of the hypothalamic mRNA expression of NPY and AgRP and significant decrease in UCP1 expression in brown adipose tissue pointing to a decreased energy expenditure. Our data suggest the hypothesis that JMV 1843 may have beneficial effects on malnutrition and cachexia induced by chronically decreased food intake. Furthermore, it can be hypothesized that the effect of JMV 1843 could be even more pronounced under the conditions of chronic cachexia, which will be the subject of future investigations by our group.

\section{Conflict of Interest}

There is no conflict of interest.

\section{Acknowledgements}

This research was supported by the Grant Agency of the Czech Republic (grant numbers 303/09/0744 and 303/10/1368), the Grant Agency of the Academy of Sciences of the Czech Republic (grant number RVO:61388963) and the Ministry of Education, Youth and Sports of the Czech Republic (grant number MSMT6046137307). The authors would like to thank Dr. A. Kiss and Dr. Z. Pirnik (Institute of Experimental Endocrinology, SAS, Slovakia) for the kind help with the isolation of the medial basal hypothalamus and H. Vysušilová for excellent technical assistance.

\section{References}

AKAMIZU T, KANGAWA K: Translational research on the clinical applications of ghrelin. Endocr J 53: 585-591, 2006.

BILLINTON CJ, BRIGGS JE, HARKER S, GRACE M, LEVINE AS: Neuropeptide Y in hypothalamic paraventricular nucleus: a center coordinating energy metabolism. Am J Physiol 266: R1765-R1770, 1994. 
BROGLIO F, BOUTIGNON F, BENSO A, GOTTERO C, PRODAM F, ARVAT E, GHÉ C, CATAPANO F, TORSELLO A, LOCATELLI V, MUCCIOLI G, BOEGLIN D, GUERLAVAIS V, FEHRENTZ JA, MARTINEZ J, GHIGO E, DEGHENGHI R: EP1572: a novel peptido-mimetic GH secretagogue with potent and selective GH-releasing activity in man. $J$ Endocrinol Invest 25: RC26-RC28, 2002.

CHEN HY, TRUMBAUER ME, CHEN AS, WEINGARTH DT, ADAMS JR, FRAZIER EG, SHEN Z, MARSH DJ, FEIGHNER SD, GUAN XM, YE Z, NARGUND RP, SMITH RG, VAN DER PLOEG LH, HOWARD AD, MACNEIL DJ, QIAN S: Orexigenic action of peripheral ghrelin is mediated by neuropeptide Y and agoutirelated protein. Endocrinology 145: 2607-2612, 2004.

CLAPHAM JC: Central control of thermogenesis. Neuropharmacology 63: 111-123, 2012.

COWLEY MA, SMITH RG, DIANO S, TSCHÖP M, PRONCHUK N, GROVE KL, STRASBURGER CJ, BIDLINGMAIER M, ESTERMAN M, HEIMAN ML, GARCIA-SEGURA LM, NILLNI EA, MENDEZ P, LOW MJ, SOTONYI P, FRIEDMAN JM, LIU H, PINTO S, COLMERS WF, CONE RD, HORVATH TL: The distribution and mechanism of action of ghrelin in the CNS demonstrates a novel hypothalamic circuit regulating energy homeostasis. Neuron 37: 649-661, 2003.

DEBOER MD, ZHU X, LEVASSEUR PR, INUI A, HU Z, HAN G, MITCH WE, TAYLOR JE, HALEM HA, DONG JZ, DATTA R, CULLER MD, MARKS DL: Ghrelin treatment of chronic kidney disease: improvements in lean body mass and cytokine profile. Endocrinology 149: 827-835, 2008.

GUERLAVAIS V, BOEGLIN D, MOUSSEAUX D, OIRY C, HEITZ A, DEGHENGHI R, LOCATELLI V, TORSELLO A, GHÉ C, CATAPANO F, MUCCIOLI G, GALLEYRAND JC, FEHRENTZ JA, MARTINEZ J: New active series of growth hormone secretagogues. $J$ Med Chem 46: 1191-1203, 2003.

HATZIIEREMIA S, KOSTOMITSOPOULOS N, BALAFAS V, TAMVAKOPOULOS C: A liquid chromatographic/ tandem mass spectroscopic method for quantification of the cyclic peptide melanotan-II. Plasma and brain tissue concentrations following administration in mice. Rapid Commun Mass Spectrom 21: 2431-2438, 2007.

KAMEGAI J, TAMURA H, SHIMIZU T, ISHII S, SUGIHARA H, WAKABAYASHI I: Chronic central infusion of ghrelin increases hypothalamic neuropeptide $\mathrm{Y}$ and Agouti-related protein mRNA levels and body weight in rats. Diabetes 50: 2438-2443, 2001.

KIM MS, NAMKOONG C, KIM HS, JANG PG, KIM PAK YM, KATAKAMI H, PARK JY, LEE KU: Chronic central administration of ghrelin reverses the effects of leptin. Int J Obes Relat Metab Disord 28: 1264-1271, 2004.

KOJIMA M, HOSODA H, DATE Y, NAKAZATO M, MATSUO H, KANGAWA K: Ghrelin is a growth-hormonereleasing acylated peptide from stomach. Nature 402: 656-660, 1999.

MALETÍNSKÁ L, MATYŠKOVÁ R, MAIXNEROVÁ J, SÝKORA D, PÝCHOVÁ M, SPOLCOVÁ A, BLECHOVÁ M, DRÁPALOVÁ J, LACINOVÁ Z, HALUZÍK M, ZELEZNÁ B: The Peptidic GHS-R antagonist [D-Lys(3)]GHRP-6 markedly improves adiposity and related metabolic abnormalities in a mouse model of postmenopausal obesity. Mol Cell Endocrinol 343: 55-62, 2011.

MALETÍNSKÁ L, PÝCHOVÁ M, HOLUBOVÁ M, BLECHOVÁ M, DEMIANOVÁ Z, ELBERT T, ŽELEZNÁ B: Characterization of new stable ghrelin analogs with prolonged orexigenic potency. $J$ Pharmacol Exp Ther 340: 781-786, 2012.

MOUSSEAUX D, LE GALLIC L, RYAN J, OIRY C, GAGNE D, FEHRENTZ JA, GALLEYRAND JC, MARTINEZ J: Regulation of ERK1/2 activity by ghrelin-activated growth hormone secretagogue receptor $1 \mathrm{~A}$ involves a PLC/PKCvarepsilon pathway. Br J Pharmacol 148: 350-365, 2006.

NAKAZATO M, MURAKAMI N, DATE Y, KOJIMA M, MATSUO H, KANGAWA K, MATSUKURA S: A role for ghrelin in the central regulation of feeding. Nature 409: 194-198, 2001.

PALUS S, SCHUR R, AKASHI YJ, BOCKMEYER B, DATTA R, HALEM H, DONG J, CULLER MD, ADAMS V, ANKER SD, SPRINGER J: Ghrelin and its analogues, BIM-28131 and BIM-28125, improve body weight and regulate the expression of MuRF-1 and MAFbx in a rat heart failure model. PLoS One 6: e26865, 2011.

PICCOLI F, DEGEN L, MACLEAN C, PETER S, BASELGIA L, LARSEN F, BEGLINGER C, DREWE J: Pharmacokinetics and pharmacodynamic effects of an oral ghrelin agonist in healthy subjects. $J$ Clin Endocrinol Metab 92: 1814-1820, 2007. 
PIRNIK Z, BUNDZIKOVÁ J, HOLUBOVÁ M, PÝCHOVÁ M, FEHRENTZ JA, MARTINEZ J, ŽELEZNÁ B, MALETÍNSKÁ L, KISS A: Ghrelin agonists impact on Fos protein expression in brain areas related to food intake regulation in male C57BL/6 mice. Neurochem Int 59: 889-895, 2011.

SMALL CJ, KIM MS, STANLEY SA, MITCHEL JR, MURPHY K, MORGAN DG, GHATEI MA, BLOOM SR: Effects of chronic central nervous system administration of agouti-related protein in pair-fed animals. Diabetes 50: 248-254, 2001.

STOFKOVA A, ZELEZNA B, ROMZOVA M, ULICNA O, KISS A, SKURLOVA M, JURCOVICOVA J: Effect of feeding status on adjuvant arthritis severity, cachexia, and insulin sensitivity in male Lewis rats. Mediators Inflamm 2010, article ID 398026, 2010.

STRASSBURG S, ANKER SD, CASTANEDA TR, BURGET L, PEREZ-TILVE D, PFLUGER PT, NOGUEIRAS R, HALEM H, DONG JZ, CULLER MD, DATTA R, TSCHÖP MH: Long-term effects of ghrelin and ghrelin receptor agonists on energy balance in rats. Am J Physiol Endocrinol Metab 295: E78-E84, 2008.

TSCHÖP M, SMILEY DL, HEIMAN ML: Ghrelin induces adiposity in rodents. Nature 407: 908-913, 2000.

TSUBONE T, MASAKI T, KATSURAGI I, TANAKA K, KAKUMA T, YOSHIMATSU H: Ghrelin regulates adiposity in white adipose tissue and UCP1 mRNA expression in brown adipose tissue in mice. Regul Pept 130: 97-103, 2005. 